論，文・Paper

\title{
及'-サイアロン加圧焼結体の酸化挙動
}

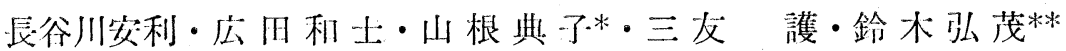

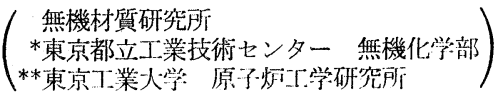

$z=1 \sim 4$ の $\beta^{\prime}$-サイアロン加圧焼結体及び $z=2$ の常圧焼結（ $\mathrm{SiO}$ ガス分圧制御）サイアロンを 们販の $\mathrm{Si}_{3} \mathrm{~N}_{4}, \mathrm{SiO}_{2}, \mathrm{AlN}$ 粉末で作製した。 サイアロンの密度は $2.853(z=1), 3.108(z=2), 2.980$ $(z=2, \mathrm{RS}), 3.095(z=3)$ 及び $3.110 \mathrm{~g} / \mathrm{ml}(z=4)$ であった. 試料は $1200^{\circ}$ 及び $1300^{\circ} \mathrm{C}$ の温度 で, 酸素ふん用気中で 720 時間 (30 日) 酸化を行った後, 重量増, X線回折, EPMA, SEM 及 び光学顕微鏡で測定した. 酸化による主成物はムライト及びクリストバライトで, 焼結体内部気泡 及び表面の酸化（第 1 段階）を経て，比較的ち密な酸化膜面を形成する (第 2 段階)。重量增は第 1 , 第 2 段階とも (時間) ${ }^{1 / 2}$ 亿比例して増加し, 第 1 , 第 2 段階の変節点は 168 時間 ( 7 日) 近辺 に認められる. 各段階における酸化割合は, 酸化温度の上昇とともに増加する. 重量増の順序は $\beta_{1}{ }^{\prime}>\beta_{2}{ }^{\prime}>\beta_{3}{ }^{\prime}>\beta_{4}{ }^{\prime}$ となり, 反対に酸化膜厚は $\beta_{1}{ }^{\prime}<\beta_{2}{ }^{\prime}<\beta_{3}{ }^{\prime}<\beta_{4}{ }^{\prime}$ となる.

(1980 作 8 月 8 月受付)

\section{Oxidation Behavior of Hot-pressed Sialon}

Yasutoshi T. HASEGAWA, Kazushi HIROTA, Tsuneko YAMANE*, Mamoru MITOMO and Hiroshige SUZUKI**

National Institute for Researches in Inorganic Materials

1-1, Namiki, Sakura-mura, Niihari-gun 305

1-1, Namiki, Sakura-mura, Niihari-gun 305
*Department of Inorganic Chemistry, Tokyo Metropolitan Industrial Technology Center
**Research Laboratory for Nuclear Reactors, Tokyo Institute of Technology

Hot-pressed $\beta^{\prime}$-sialon $(z=1 \sim 4)$ and reaction sintered $\beta_{2}^{\prime}$ "balanced" sialon were prepared from commercial grade $\mathrm{Si}_{3} \mathrm{~N}_{4}, \mathrm{SiO}_{2}$ and AlN powder. Densities of sialon were $2.853(z=$ 1), $3.108(z=2), 2.980(z=2, \mathrm{RS}), 3.095(z=3)$ and $3.110 \mathrm{~g} / \mathrm{ml} \quad(z=4)$. Specimens were oxidized in dry oxygen at temperature $1200^{\circ}$ and $1300^{\circ} \mathrm{C}$ for up to $720 \mathrm{~h}(30 \mathrm{~d})$, and characterized by measurements of weight gain, X-ray diffraction, EPMA, SEM and microscopy. The main oxidation products were mullite and cristobalite which formed around internal pores and surface (stage 1), and eventually as a relative dense oxidized layer (stage 2). The weight gain in each stage is proportional to (time) $)^{1 / 2}$ and erratic point between stage 1 and stage 2 appear at about $168 \mathrm{~h}(7 \mathrm{~d})$. The rate of oxidation in each stage increases with increasing temperature. The weight gain of oxidized samples are as follows : $\beta_{1}{ }^{\prime}>\beta_{2}{ }^{\prime}>\beta_{3}{ }^{\prime}>\beta_{4}{ }^{\prime}$

But the mean thickness of oxidized layer, as contrasted with the weight gain, are as follows:

$$
\beta_{1}{ }^{\prime}<\beta_{2}{ }^{\prime}<\beta_{3}{ }^{\prime}<\beta_{4}{ }^{\prime}
$$

[Received August 8, 1980]

Key-words : Sialon, Hot-pressing (RS $z=2$ ), Oxidation, Mullite, Oxidized layer

\section{1. 緒言}

$\mathrm{Si}, \mathrm{Al}, \mathrm{O}$ 及び $\mathrm{N}$ の 4 成分から成る化合物，固溶体 は 1972 年に日本及び英国で，ほとんど同時に独立に 研究発表され ${ }^{1,2)}$, 以後サイアロン (sialon) と称され ている3 $. \mathrm{Si}_{3} \mathrm{~N}_{4}-\mathrm{AlN}-\mathrm{Al}_{2} \mathrm{O}_{3}-\mathrm{SiO}_{2}$ 系の相図に扮い ( (4) 8)， $\beta^{\prime}$-sialon $1 \mathrm{Si}_{8} \mathrm{~N}_{4}$ と $\mathrm{AlN}-\mathrm{Al}_{2} \mathrm{O}_{3}$ を結ぶ線上
にあり， $\beta-\mathrm{Si}_{3} \mathrm{~N}_{4}$ 構造に $\mathrm{Al}, \mathrm{O}$ 原子が固溶した物質で 汤る. サイアロンは優れた機械的, 熱的性質をもってお り，また耐化学性も良好であり， $\mathrm{Si}_{3} \mathrm{~N}_{4}, \mathrm{SiC}$ 等ととも に高温耐熱材料として今後の発展が期待されている物質 である．またサイアロンは焼結助剤を添加しないで，比 較的容易に高密度焼結体が得られる。最近では常圧焼結 
(RS) でも $\mathrm{SiO}$ ガス分圧制御法によって極めて優れた特 性（†真比重）をもつサイアロンが得られるようになっ $た^{9,10)}$. しかしながらサイアロンの酸化に関する系統的 かつ長期にわたる研究は現在のところほとんどなく，ま た酸化時間も比較的短( ${ }^{(1) ~ 14) . ~}$

著者らは, $\mathrm{Si}_{3} \mathrm{~N}_{4}-\mathrm{AlN}-\mathrm{SiO}_{2}$ 系サイアロン加圧焼結体 $\beta^{\prime}(z=1 \sim 4)$ 及び常圧焼結によって得られた $z=2$ のサ イアロン供試体について, 純酸素ふん囲気中で 24 時間 (1d) から 720 時間 $(30 \mathrm{~d})$ にわたる酸化実験を行い, 酸化による重量増と酸化膜の関係, 酸化生成物及び酸化 膜の性状について研究し, 酸化の機構について 考察し た.

\section{2. 実験方法}

\section{1 原: 料}

窒化ケイ素 $\left(\mathrm{Si}_{3} \mathrm{~N}_{4}\right)$ は前報で記述した ${ }^{15), 16)}, \mathrm{AME}$ 社 (Advanced Materials Eng.) 製を，窒化アルミニウム (AlN) は東京芝浦電気社製 (Al 65.0，N 32.3，O 1.42, Si $0.13, \mathrm{Fe} 0.14 \mathrm{wt} \%)$ を，ケイ素 $\left(\mathrm{SiO}_{2}\right)$ は和光純薬 社製沈降製無水ケイ酸（特級品）を使用した. 出発原料 の混合, 粉砕は高純度めのう製ボールミルで各 1 時間行 った. 本酸化実験で用いた組成は下記反応式 ${ }^{17)}$ におい て, $z=1,2,3,4$ とした. 混合, 粉砕時のめのう製ボ 一ルミルからのシリカの混入はあらかじめブランクテス トにより考慮してあり, 混合, 粉砕後の組成が所定の少 イアロンになるようにした。

$$
\begin{aligned}
(4-z) \mathrm{Si}_{8} \mathrm{~N}_{4}+ & z \mathrm{SiO}_{2}+2 z \mathrm{AlN} \\
& \rightarrow 2 \mathrm{Si}_{6-z} \mathrm{Al}_{z} \mathrm{O}_{z} \mathrm{~N}_{8-z}
\end{aligned}
$$

表 1 に混合組成を示した.

\section{2 ホットプレス}

上記で調製した混合粉末約 $40 \mathrm{~g}$ をひょう量し， BN で被覆した内径 $50 \mathrm{~mm} \phi$ の黒鉛型に入れ， $\mathrm{N}_{2}$ ふん囲気 中で $200 \mathrm{~kg} / \mathrm{cm}^{2}$ の圧力下で $1750^{\circ} \mathrm{C}$ に 1 時間保持し, 和・サイアロンの加圧焼結体を得た.

Table 1. The mixing ratio of starting powder.

\begin{tabular}{llcccc}
\hline $\mathrm{z}$ & $\mathrm{Si}_{6-\mathrm{z}} \cdot \mathrm{Al}_{\mathrm{z}} \cdot \mathrm{O}_{\mathrm{z}} \cdot \mathrm{NN}_{8-\mathrm{z}}$ & $\mathrm{Si}_{3} \mathrm{~N}_{4}$ & $\mathrm{AlN}$ & $\mathrm{SiO}_{2}$ & (mol) \\
\hline 1 & $\mathrm{Si}_{5} \cdot \mathrm{Al} \cdot 0 \cdot \mathrm{N}_{7}$ & 3 & 2 & 1 & \\
2 & $\mathrm{Si}_{4} \cdot \mathrm{Al}_{2} \cdot \mathrm{O}_{2} \cdot \mathrm{N}_{6}$ & 2 & 4 & 2 & \\
3 & $\mathrm{Si}_{3} \cdot \mathrm{Al}_{3} \cdot \mathrm{O}_{3} \cdot \mathrm{N}_{5}$ & 1 & 6 & 3 & \\
4 & $\mathrm{Si}_{2} \cdot \mathrm{Al}_{4} \cdot \mathrm{O}_{4} \cdot \mathrm{N}_{4}$ & 0 & 8 & 4 & \\
\hline
\end{tabular}

Table 2. Bulk densities and porosities in

\begin{tabular}{|c|c|c|c|}
\hline $\mathrm{z}$ & bulk density & $\mathrm{d} \mathrm{cal}^{9)}\left(\mathrm{g} / \mathrm{cm}^{3}\right)$ & porosity (\%) \\
\hline 1 & 2.853 & 3.151 & 9.46 \\
\hline 2 & 3.108 & 3.112 & 0.13 \\
\hline 2 (R.S.) & 2.980 & 3.112 & 4.24 \\
\hline 3 & 3.095 & 3.070 & - \\
\hline 4 & 3.110 & 3.045 & - \\
\hline
\end{tabular}
sintered sialon.

\section{3 焼結体の切断, 研磨}

加圧焼結後, 試料を取り出し, \#150 及び \#600のダ イアモンドホイールにて両面研磨し, 厚みを約 $1 \mathrm{~mm}$ と した. 正確に寸法測定し, かさ比重の測定結果及び気孔 率を表 2 に示した（表の中で $z=2$ のサイアロン (RS) は $1800^{\circ} \mathrm{C}, 1.4$ 時間, $\mathrm{SiO}$ ガス分圧制御下で常圧燒結し たものを所定のサイズに切断，研磨したものである). 次 いでダイアモンドブレードで $10 \times 10 \mathrm{~mm}$ のサイズに切 断し， $10 \times 10 \times 1 \mathrm{~mm}$ の供試体を製作した. 各面を更に \# 1000 及び \# 2000 の $\mathrm{SiC}$ 粉末で研磨した後, アセ卜 ン及びアルコールにて超音波洗浄後，マイクロメーター で供試体のサイ。ズを測定し, 次いで減圧乾燥機で $80^{\circ} \mathrm{C}$, 24 時間乾燥後, マイクロバランスで $\pm 0.00001 \mathrm{~g}$ の精 度でひょう量した:

\section{4 酸化}

高純度アルミナボートに，それぞれ計量した試料をの せ, $\mathrm{SiC}$ 加熱炉中のアルミナ反応管中にそう入し, 乾燥 した 純酸素を $300 \mathrm{ml} / \mathrm{min}$ で流しながら， $1200^{\circ}$ 及び $1300^{\circ} \mathrm{C}$ に加熱, 恒温に保持し, 所定の時間 (24, 72 , 168，360 及び $720 \mathrm{~h}$ ) 酸化した後, 試料を取り出し, 室温に泠却後マイクロバランスによる重量測定，X線回 折による試料表面に生成した酸化膜の鉱物同定，次いで SEM による酸化膜表面及び破断面の性状観察後, 試料 をダイアモンドカッターにより切断し，切断面を研磨し た後光学顕微鏡による切断面 (特に酸化膜) の観察, 次 いで EPMA による酸化膜内の不純物分布を測定するこ とによって, 酸化膜厚を計測した.

$\mathrm{Si}_{6-z} \mathrm{Al}_{z} \mathrm{O}_{z} \mathrm{~N}_{8-z}$ の $z=1 ， 2 ， 3 ， 4$ に相当する焼結 体をそれぞれ $\beta_{1}{ }^{\prime} ， \beta_{2}{ }^{\prime} ， \beta_{3}{ }^{\prime} ， \beta_{4}{ }^{\prime}$ とする.

\section{3. 実験結果及び考察}

\section{1 酸化による重量増及び酸化膜厚}

図 1 に $1200^{\circ} \mathrm{C}$, 図 2 に $1300^{\circ} \mathrm{C}$ における $24 \sim 720 \mathrm{~h}$ の 酸化時間による重量増 $\left(\mathrm{mg} / \mathrm{cm}^{2}\right)$ を示した. $1200^{\circ}$ 及び $1300^{\circ} \mathrm{C}$ のいずれも重量増は $\beta_{4}{ }^{\prime}$ から $\beta_{1}{ }^{\prime}$ の順にしたが って増加している. 特に $\beta_{1}{ }^{\prime}$ の重量増は $\beta_{2}{ }^{\prime}$ 及び $\beta_{3}{ }^{\prime}$ に比し, 増加量が大きい.

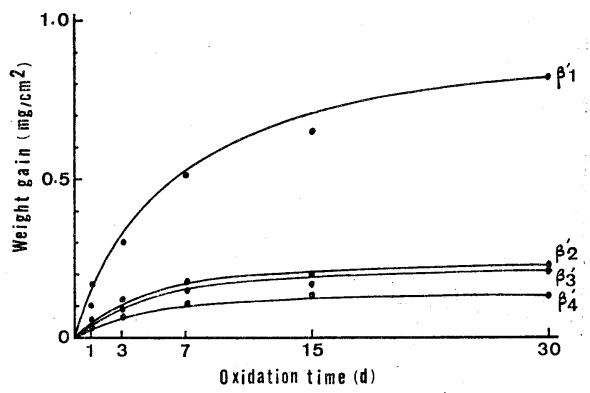

Fig. 1. Weight gain curves vs. oxidation time at $1200^{\circ} \mathrm{C}$ in dry oxygen. 
一般に酸化による重量増は放物線則に従うとされる.

$$
W^{2}=K_{\mathrm{p}} \cdot t
$$

ただし, $K_{\mathrm{p}}$ : 定数, $W$ : 酸化による重量増, $t$ : 酸化時 閒として, $W-(t)^{1 / 2}$ の関係を図 3,4 に示した. $1200^{\circ} \mathrm{C}$ 及び $1300^{\circ} \mathrm{C}$ のいずれの場合も，酸化が単一拡散によ る律速でないことを示し，第 1 段階，第 2 段階（図の stage 1 , stage 2) と区別して考えられる. 第 1 段階は $1200^{\circ} \mathrm{C}$ 及び $1300^{\circ} \mathrm{C}$ のいずれの酸化も，酸化時間が $7 \mathrm{~d}$ 近辺, 以後は第 2 段階といえる. 第 1 段階では酸化によ る重量増が比較的多く, 第 2 段階では微増である. 従来

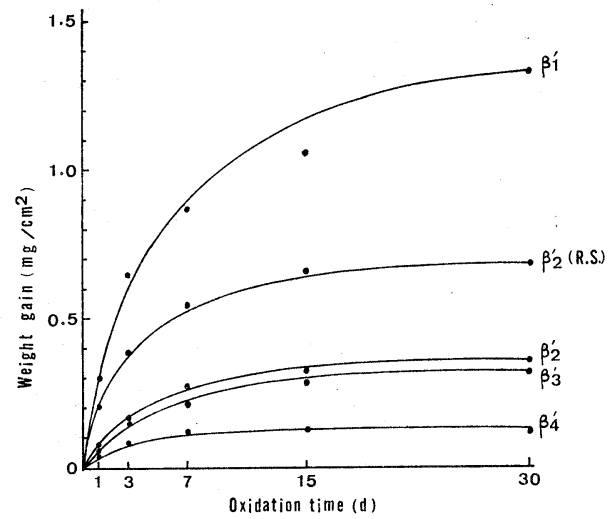

Fig. 2. Weight gain curves vs. oxidation time at $1300^{\circ} \mathrm{C}$ in dry oxygen.

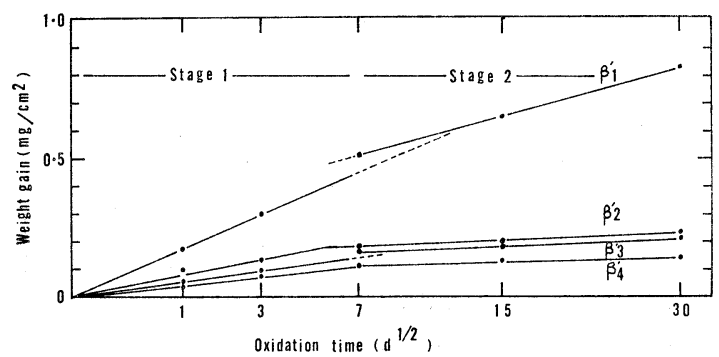

Fig. 3. Weight gain vs. (oxidation time) ${ }^{1 / 2}$ at $1200^{\circ} \mathrm{C}$ in dry oxygen.

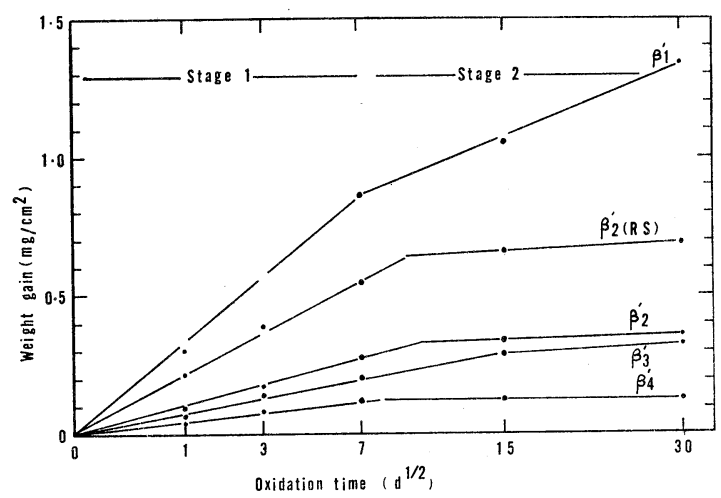

Fig. 4. Weight gain vs. (oxidation time) $)^{1 / 2}$ at $1300^{\circ} \mathrm{C}$ in dry oxygen.
の酸化に関する報告では，酸化の初期段階として急速な 重量増があり， $1200^{\circ} \sim 1400^{\circ} \mathrm{C}$ 酸化時には $15 \sim 60 \mathrm{~min}$ 近辺に存在する ${ }^{14)}$ とあるが，本研究では測定時間の関係 から，この初期段階における重量増は無視した. 第 1 段 階，第 2 段階という“erratic”な酸化挙動に関しては前 報 $^{16)}$ にて記述したが, 本研究にても同じ挙動が観察され る.これは酸化が単一な拡散機構で進行しないことを意 味している. 第 1 段階と第 2 段階の酸化機構に関して は, SEM による酸化膜の表面, 断面等の酸化時間によ る変化の観察及び光学顕微鏡による切断面の観察等によ った考察を後述する.

酸化による酸化膜の生成時には，焼結体中の結晶粒界 に存在する不純物が酸化膜に集積することは前述し た ${ }^{15), 16)}$. この不純物の集積を EPMA で測定すること によって，容易に酸化膜の厚みを測定することが可能で ある. 図 5, 6 にその測定結果を示す. 重量增とは逆に, 酸化温度 $1200^{\circ}$ 及び $1300^{\circ} \mathrm{C}$ の場合において $\beta_{1}{ }^{\prime}$ から $\beta_{4}{ }^{\prime}$ の順に膜厚は増加している.この現象は次に示す酸

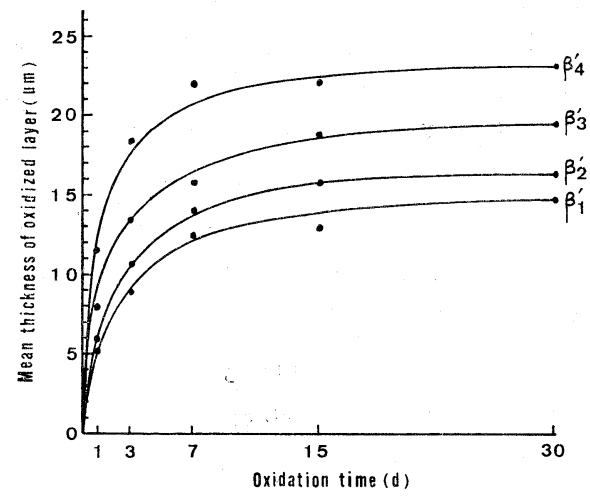

Fig. 5. Mean thickness of oxidized layer in $\beta^{\prime}$-sialon (at $1200^{\circ} \mathrm{C}$ in dry oxygen) measured by EPMA.

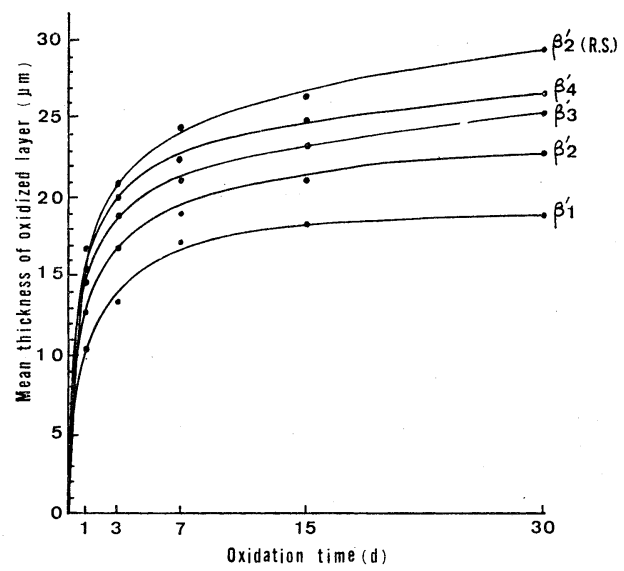

Fig. 6. Mean thickness of oxidized layer in $\beta^{\prime}$-sialon (at $1300^{\circ} \mathrm{C}$ in dry oxygen) measured by EPMA. 
化反応式によって容易に理解できる (表 3 参照) . 酸化に よって生成するのが，ムライト $\left(3 \mathrm{Al}_{2} \mathrm{O}_{3} \cdot 2 \mathrm{SiO}_{2}\right)$, シリ 力 $\left(\mathrm{SiO}_{2}\right)$ 及び $\mathrm{N}_{2}$ として, 反応式中の $\mathrm{A}$ から $\mathrm{E}$ までの 係数計算結果を表 3 に示した. $z=1 \sim 4$ までサイアロン の式量はほとんど一定であるから，酸化前のサイアロン （ $z=1 \sim 4 ）$ のル数を一定とし， 酸化によって生成したムライト及 びシリカの生成重量を酸化膜重量 として，酸化による単位体積当た りの重量增 $\left(\mathrm{mg} / \mathrm{cm}^{2} \times 10 \mu \mathrm{m}\right)$ 及 び膜厚 $\left(\mu \mathrm{m} /\left(\mathrm{mg} / \mathrm{cm}^{2}\right)\right)$ の計算結 果を併記した.

実験結果と比較すると，酸化に よる重量増の場合, $\beta_{1}{ }^{\prime}$ は $\beta_{4}{ }^{\prime}$ の 1.529 倍 (計算値), $30 \mathrm{~d}$ 酸化の 実測值は $1200^{\circ} \mathrm{C}$ で 5.929 倍, $1300^{\circ} \mathrm{C}$ で 11.25 倍となり, 実測 值は計算值に比し，はるかに大き い.これの主たる原因の一つとし て, 供試体の気孔率が考えられ る. 初期酸化(図 3, 4 の stage 1) においては表面酸化と並行して, 燒結体内部に拡散した $\mathrm{O}_{2}$ 又は $\mathrm{O}^{2-}$ による内部気孔内表面の酸化 が同時進行し, 見掛けの重量増加 に寄与している. 図 3，4 に示し た stage 1 の領域が，焼結体内部 気孔の同時酸化を意味し, stage 2 では表面酸化のみの現象と考え れば,このギャップは説明できよ う. $\beta_{1}{ }^{\prime}$ から $\beta_{4}{ }^{\prime}$ に至る酸化によ る重量増の結果は, Singhal らの 酸化実験とも一致している ${ }^{11}$.

$\mathrm{Si}_{3} \mathrm{~N}_{4}-\mathrm{Y}_{2} \mathrm{O}_{3}-\mathrm{Al}_{2} \mathrm{O}_{3}$ の酸化膜 厚 ${ }^{15)}, \mathrm{Si}_{3} \mathrm{~N}_{4}-\mathrm{MgO}$ の酸化膜厚 ${ }^{16)}$ に比し, サイアロンの酸化膜厚 は, 最も厚い酸化膜厚をもつ $\beta_{2}^{\prime}$ (RS) で比較しても, $30 \mathrm{~d}, 1300^{\circ} \mathrm{C}$ において $1 / 2 \sim 1 / 3$ 程度であり， 酸化による重量増とともに耐酸化 性は優れている.

\section{2 酸化生成物}

表 4 にX線回折による試料表面 に生成した酸化膜の生成物の同定 結果と酸化温度と時間 との関係 を, 図 7 にムライト及びクリスト バライトのX線回折ピークの比較 強度と酸化時間, 温度についての
Table 3. Oxidation reaction of sintered $\beta^{\prime}$-sialon.

A. $\left(\mathrm{Si}_{6-\mathrm{z}} \cdot \mathrm{Al}_{\mathrm{z}} \cdot \mathrm{O}_{\mathrm{z}} \cdot \mathrm{N} 8-\mathrm{z}\right)+\mathrm{B} \cdot \mathrm{O}_{2}=\mathrm{C} \cdot\left(3 \mathrm{Al}_{2} \mathrm{O}_{3} \cdot 2 \mathrm{SiO}_{2}\right)+\mathrm{D} \cdot \mathrm{SiO}_{2}+\mathrm{E} \cdot \mathrm{N}_{2}$

\begin{tabular}{rrrrrrrrcc} 
Z & A & B & C & D & E & (mol) & m.w. of sialon & $\begin{array}{c}\text { weight gain } \\
\left(\mathrm{mg} / \mathrm{cm}^{2} \times 10 \mu \mathrm{m}\right)\end{array}$ & $\begin{array}{c}\text { thickness } \\
{\left[\mathrm{mm} /\left(\mathrm{mg} / \mathrm{cm}^{2}\right]\right.}\end{array}$ \\
\hline 1 & 12 & 71 & 2 & 64 & 42 & 281.5 & 0.572 & 17.48 \\
2 & 12 & 54 & 4 & 40 & 36 & 282.4 & 0.459 & 21.79 \\
3 & 12 & 45 & 6 & 24 & 30 & 279.3 & 0.421 & 23.75 \\
4 & 12 & 36 & 8 & 8 & 24 & 280.2 & 0.374 & 26.74 \\
\hline
\end{tabular}

Table 4. Minerals detected by X-ray diffraction on the surface of oxidized sample.

1) Oxidized at $1200^{\circ} \mathrm{C}$

\begin{tabular}{|c|c|c|c|c|c|c|}
\hline sarnple & time (d) & $\beta$-silicon nitride & mullite & cristobalite & $\mathrm{X}$-phase & sialon \\
\hline \multirow[t]{6}{*}{$\beta^{\prime} 1$} & 0 & Vw & - & - & - & vS \\
\hline & 1 & $\mathrm{VW}$ & Tr. & VW & - & vs \\
\hline & 3 & $\mathrm{vw}$ & $\mathrm{Tr}$. & $\mathrm{w}$ & - & vs \\
\hline & 7 & VW & $\operatorname{Tr}$. & $\mathrm{W}$ & - & $\mathrm{s}$ \\
\hline & 15 & VW & VW & M & - & $\mathrm{s}$ \\
\hline & 30 & VW & VW & M & - & M \\
\hline \multirow[t]{6}{*}{$\beta^{\prime} 2$} & 0 & $\operatorname{Tr}$. & - & - & - & vs \\
\hline & 1 & $\operatorname{Tr}$. & $\operatorname{Tr}$. & - & - & vs \\
\hline & 3 & $\operatorname{Tr}$. & vw & - & - & vs \\
\hline & 7 & Tr. & vw & Tr. & - & vs \\
\hline & 15 & $\operatorname{Tr}$. & $\mathrm{VW}$ & VW & - & vs \\
\hline & 30 & $\operatorname{Tr}$. & vw & $\mathrm{vW}$ & - & vs \\
\hline \multirow[t]{6}{*}{$\beta^{\prime} 3$} & 0 & - & - & - & $\mathrm{Tr}$. & vS \\
\hline & $I$ & - & vw & - & $\mathrm{Tr}$. & vs \\
\hline & 3 & - & $\mathrm{VW}$ & - & Tr. & vs \\
\hline & 7 & - & VW & - & $\mathrm{Tr}$. & vs \\
\hline & 15 & - & Vw & Tr. & $\operatorname{Tr}$. & vs \\
\hline & 30 & - & $\mathrm{W}$ & $\operatorname{Tr}$. & $\operatorname{Tr}$. & vs \\
\hline \multirow[t]{6}{*}{$\beta_{4}^{\prime}$} & 0 & - & - & - & $\mathrm{Tr}$. & vs \\
\hline & 1 & - & $\mathrm{VW}$ & - & $\operatorname{Tr}$. & vs \\
\hline & 3 & - & VW & - & $\operatorname{Tr}$. & VS \\
\hline & 7 & - & $\mathrm{W}$ & - & $\operatorname{Tr}$. & vs \\
\hline & 15 & - & W & - & Tr. & VS \\
\hline & 30 & - & $M$ & - & $\operatorname{Tr}$. & vs \\
\hline
\end{tabular}

2) oxidized at $1300^{\circ} \mathrm{C}$

\begin{tabular}{|c|c|c|c|c|c|c|}
\hline sample & time (d) & $\beta$-silicon nitride & mullite & cristobalite & $\mathrm{X}$-phase & sialor \\
\hline \multirow[t]{5}{*}{$\beta^{\prime} 1$} & 1 & VW & viv & VW & - & vs \\
\hline & 3 & vW & $\mathrm{VW}$ & M & - & vs \\
\hline & 7 & $\mathrm{VW}$ & $\mathrm{VW}$ & M & - & $\mathrm{s}$ \\
\hline & 15 & VW & W & $\mathrm{M}$ & - & s \\
\hline & 30 & VW & $\mathrm{W}$ & $\mathrm{s}$ & - & M \\
\hline \multirow[t]{5}{*}{$\beta \hat{2}$} & 1 & Tr. & VW & Tr. & - & vs \\
\hline & 3 & Tr. & Vw & Tr. & - & vs \\
\hline & 7 & Tr. & w & Tr. & - & vs \\
\hline & 15 & Tr. & $\mathrm{w}$ & $\operatorname{Tr}$. & - & vs \\
\hline & 30 & $\operatorname{Tr}$. & W & VW & - & vs \\
\hline \multirow[t]{5}{*}{$\beta^{\prime} 2 \quad$ (R.S.) } & 1 & - & $\mathrm{VW}$ & $\operatorname{Tr}$. & Tr. & vs \\
\hline & 3 & - & $\mathrm{VW}$ & $\operatorname{Tr}$. & $\operatorname{Tr}$. & vs \\
\hline & 7 & - & $\mathrm{W}$ & $\operatorname{Tr}$. & Tr. & vs \\
\hline & 15 & - & $\mathrm{W}$ & $\mathrm{VW}$ & Tr. & vs \\
\hline & 30 & - & $\mathrm{w}$ & VW & $\operatorname{Tr}$ & vs \\
\hline \multirow[t]{5}{*}{$\beta^{\prime} 3$} & 1 & - & VW & Tr. & - & vs \\
\hline & 3 & - & $\mathrm{W}$ & $T x$ & - & vs \\
\hline & 7 & - & W & $\operatorname{Tr}$. & $\mathrm{Tr}$. & vs \\
\hline & 15 & - & $\mathrm{W}$ & $\operatorname{Tr}$. & $\operatorname{Tr}$. & vs \\
\hline & 30 & - & $M$ & Tr. & $\operatorname{Tr}$. & VS \\
\hline \multirow[t]{5}{*}{$\beta^{\prime} 4$} & 1 & - & $W$ & - & - & vs \\
\hline & 3 & - & W & - & - & vs \\
\hline & 7 & - & $\mathrm{M}$ & - & - & $\mathrm{S}$ \\
\hline & 15 & - & $M$ & - & - & s \\
\hline & 30 & - & $\mathrm{M}$ & - & - & $s$ \\
\hline
\end{tabular}




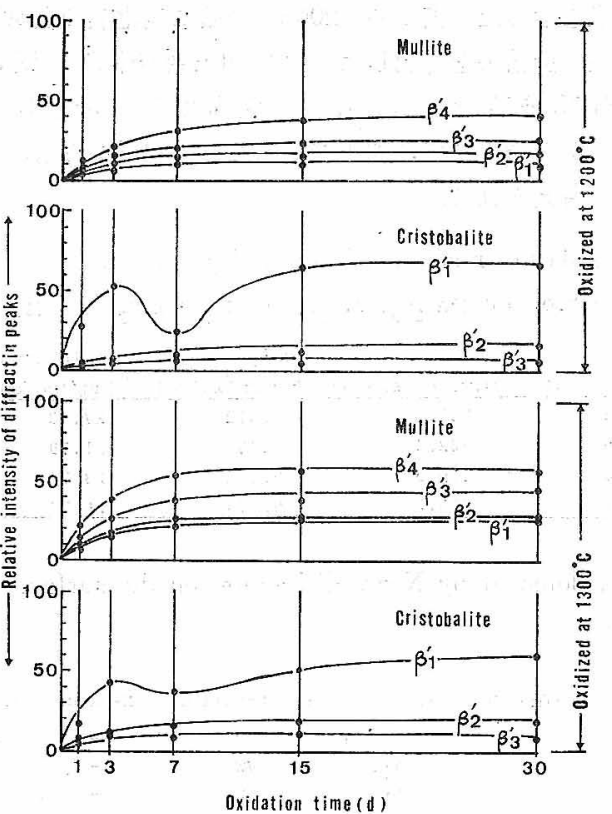

Fig. 7. Relative intensities of X-ray diffraction peaks of mullite and cristobalite. $1200^{\circ} \mathrm{C}$ の酸化では，未反忘の $\beta-\mathrm{Si}_{3} \mathrm{~N}_{4}$ 荙若干含む $\beta_{1}{ }^{\prime}$ は酸化時閒が增加するにしたがって，クリストバライト の生成量が増加するが， $\beta-\mathrm{Si}_{8} \mathrm{~N}_{4}$ を含まない単相の $\beta_{3}{ }^{\prime}$, $\beta_{4}{ }^{\prime}$ になるにつれて, クリストバライトの生成量は減少 し，主としてムライトが主成分になる傾向がある． $\beta_{1}{ }^{\prime}$ のクリストバライトの挙動は, $\mathrm{Si}_{3} \mathrm{~N}_{4}-\mathrm{Y}_{2} \mathrm{O}_{3}-\mathrm{Al}_{2} \mathrm{O}_{3}$ 酸化 時のクリストバライトの挙動 ${ }^{15)}$ と同じ傾向を示し, 酸化 時間が $3 \mathrm{~d}$ 近辺までは急速にクリストバライトのX線強 度は増加し, 以後 $7 \mathrm{~d}$ 近辺まで減少後再び増加の傾向を たどる. $1300^{\circ} \mathrm{C}$ 酸化時間でも同じ挙動を示す。これは 酸化初期に供試体表面あるいは内部に存在する未反応の $\beta-\mathrm{Si}_{3} \mathrm{~N}_{4}$ が下記反応によって,

$$
\begin{aligned}
& \mathrm{Si}_{3} \mathrm{~N}_{4}+5 \mathrm{O}_{2} \rightarrow 3 \mathrm{SiO}_{2}+4 \mathrm{NO}^{18)} \\
& 2 \mathrm{NO}=\mathrm{N}_{2}+\mathrm{O}_{2}
\end{aligned}
$$

$\mathrm{SiO}_{2}$ が生成し，クリストバライトになる。，一方，焼結 体粒界層に存在する不純物は酸化膜に移動し，クリス卜 バライトの一部はシリケートガラスになる。クリストバ ライトの生成速度に対して，不純物の酸化膜への集積に よるシリタートガラス化の速度が $7 \mathrm{~d}$ 近辺で最大とな り，酸化時間が更に増加すると，クリストバライトに対

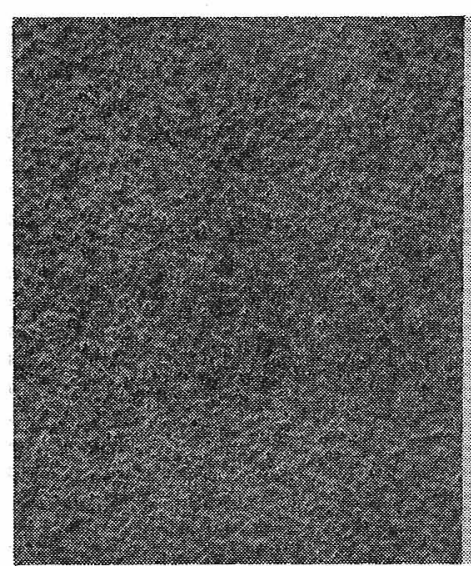

$0 \mathrm{~d}$

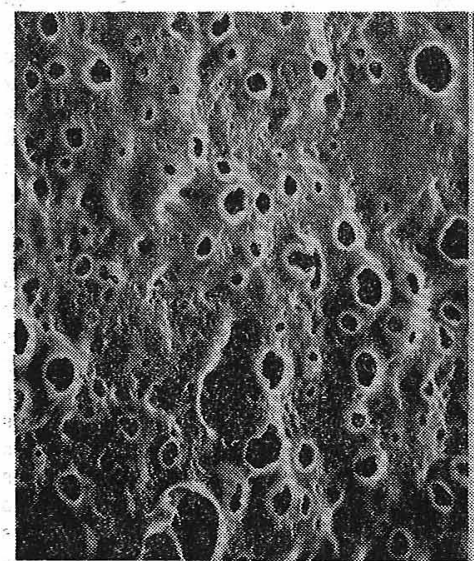

$7 d$

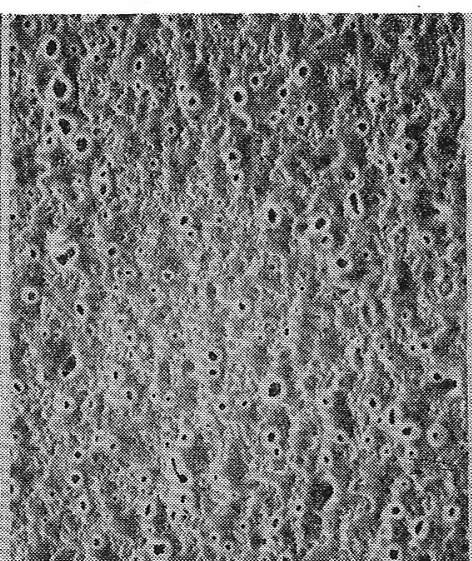

$1 \mathrm{~d}$

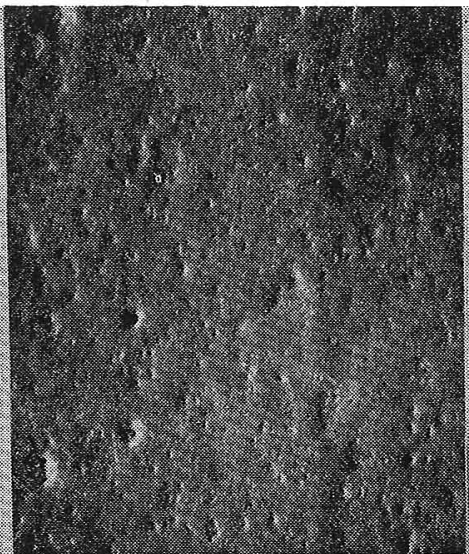

$15 \mathrm{~d}$

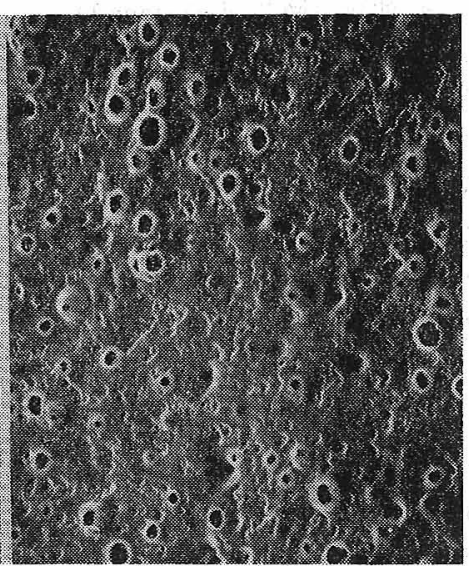

$3 \mathrm{~d}$

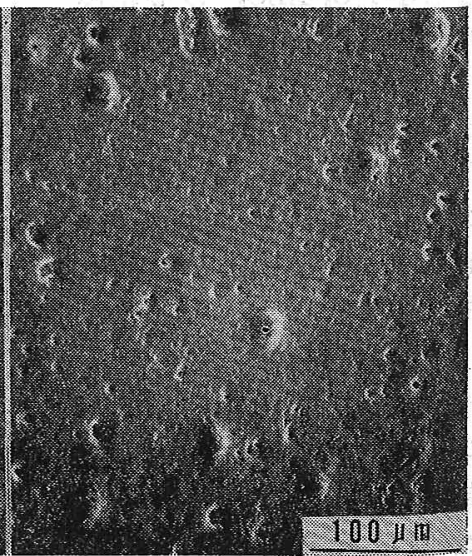

$30 \mathrm{~d}$

Fig. 8. SEM observation of oxidized surface of $\beta_{2}{ }^{\prime}$ (RS) "balanced" sialon at $1300^{\circ} \mathrm{C}$. 
するシリケートガラスの相効量が減少することを意味し ている.

一方, $\mathrm{SiO}_{2}-\mathrm{Al}_{2} \mathrm{O}_{3}$ 系にお打るムライトの生成温度 ${ }^{199}$ 加ら推定した場合， $1200^{\circ} \mathrm{C}$ の酸化温度で試料表面にム ライトが生成する事実は，焼結体粒界層に存在する不純 物の酸化膜への集積，その影響による反応生成温度の低 下によってムライトが生成すると考えられる。(3) 式か らも明らかなように， $\beta_{1}{ }^{\prime}$ 加ら $\beta_{4}{ }^{\prime}$ になるにしたがって ムライトの生成量は増加するが，クリストバライトは減 少する. 特に $\beta_{4}^{\prime}$ のX線回折結果ではクリストバライト の存在は認められなかった。

\section{3 酸化膜の性状}

\subsubsection{SEM による酸化膜の表面観察}

酸化による試料表面の酸化膜表面形状の変化の一例を 図 8，9 に示した. 酸化による重量増で前述した第 1 段 階と第 2 段階の酸化機構の変節点 (erratic behavior) が $7 \mathrm{~d}$ 近辺であることを示したが, 図 8 の表面形状を観察 すると，1d から $7 \mathrm{~d}$ に至る酸化では，表面に無数のピ ットが散見される.これは (3)，(4) 式に示した反応で生 成した $\mathrm{N}_{2}$ 及び $\mathrm{NO}$ ガスが, 主としてクリストバライ
ト，ムライト及びシリケートガラスからなる酸化膜内で 気泡となり,表面に放出されたためのピットである、酸化 の進行とともにピットは減少するが，ピットの孔径増 大の傾向にある.このピットを通じて,試料の表面酸化と 同時に, 燒結体内部の気孔内表面酸化が進行する（図 3, 4 の stage 1). $7 \mathrm{~d}$ 以後, 酸化膜表面のピットは急速に 減少し，試料表面はわずかにピンホールのようなピット が散見される比較的平滑な面になる.この傾向は $\beta_{1}{ }^{\prime}$ 及 び $\beta_{2}{ }^{\prime}$ ( $\beta_{2}{ }^{\prime}$ (RS) を含む) に共通して観察され， $\beta_{3}{ }^{\prime}$ 加 ら $\beta_{4}{ }^{\prime}$ になるにしたがって，この現象は消失する（酸化 生成物の主成分がほとんどムライトの場合)。

\subsubsection{SEM. による酸化膜破断面の観察}

図 10 に SEM による酸化時間 $30 \mathrm{~d}$ の酸化膜破断面 の一例を示した。 ' $\beta_{1}{ }^{\prime}$ は比較的ち密な層を形成している が， $\beta_{2}{ }^{\prime}$ から $\beta_{4}{ }^{\prime}$ に移行するにしたがって，酸化膜は次 第に多孔質になっている. これは図 7 からも考察される ように，クリストバライトの生成量の大きい $\beta_{1}{ }^{\prime}$ 牥，酸 化の進行とともに焼結体粒界層中に存在する不純物（特 に液相形成イオン）の酸化膜への集積により一部はシリ ケートガラスに変化する.このために酸化膜中のクリス

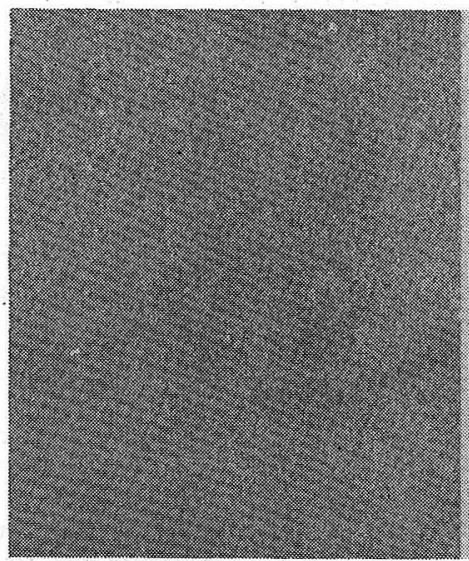

$0 \mathrm{~d}$

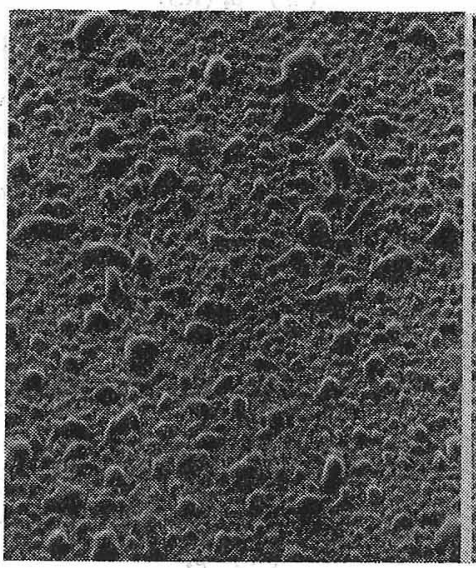

$7 \mathrm{~d}$

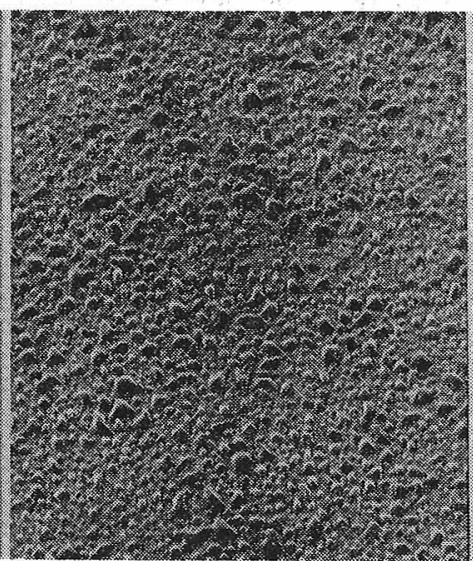

$1 \mathrm{~d}$

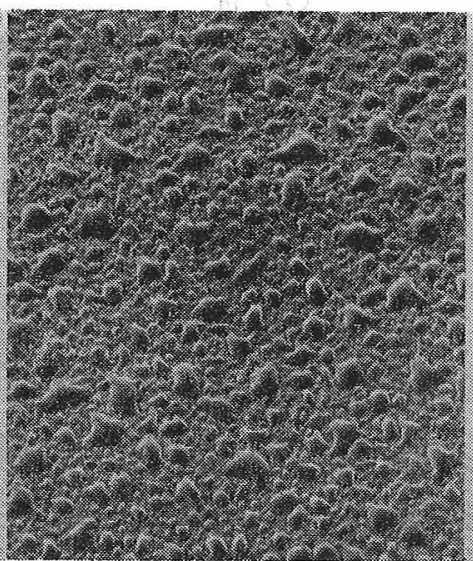

$15 \mathrm{~d}$

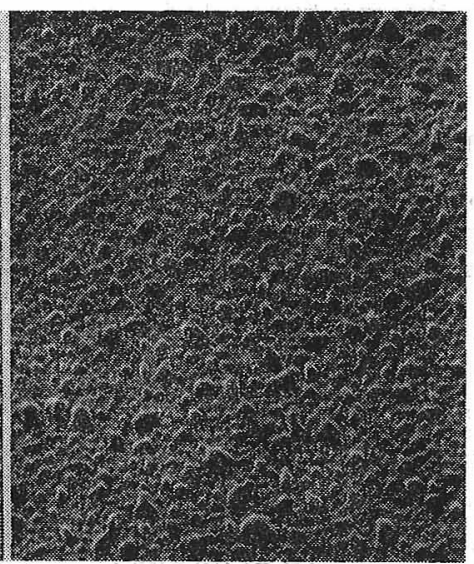

$3 d$

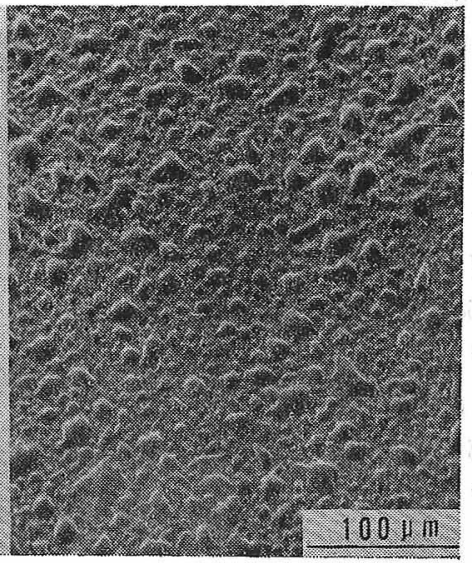

$30 \mathrm{~d}$

Fig. 9. SEM observation of oxidized surface of $\beta_{3}{ }^{\prime}$-sialon at $1300^{\circ} \mathrm{C}$. 
トバライト，ムライト等の結晶粒 界に,このシリケートガラスが充 てんし，ち密な相を形成する，一 方 $\beta_{2}{ }^{\prime}$ から $\beta_{4}{ }^{\prime}$ に移行するにした がい，クリストバライト生成量は 減少し（必然的にシリケートガラ スの生成も減少子る), 比較的ポ 一ラスな酸化層を形成する。

\subsection{3 光学顕微鏡による酸化} 膜研磨面の観察

図 11 に酸化時間 $30 \mathrm{~d}$, 酸化湿. 度 $1300^{\circ} \mathrm{C}$ の酸化膜研磨面の光学 顕徴鏡による観察結果の一例を示 した. SEM による破断面の観察 結果と同じ傾向を示しており， $\beta_{1}^{\prime}$ はシリケートガラスを比較的多量 に含んだら密な酸化層を形成して おり, 2 15 $\mu \mathrm{m}$ 程度の気泡群が散 見される。 $\beta_{2}{ }^{\prime}$ (RS) は $10 \sim 15 \mu \mathrm{m}$ 程度の気泡が散見されるが，比較 的ち密な層を形成している。 $\beta_{8}^{\prime}$ から $\beta_{4}^{\prime}$ になるにしたがってガラ ス相は減少し, 微細な結晶群の集 合層になっている. 以上の現象 は，X線回折及び SEM による表 面庈び破断面の観察からも説明で きよう. $1200^{\circ} \mathrm{C}$ において, $\beta_{1}{ }^{\prime}$ は 数 $\mu \mathrm{m}$ 以下の微細気泡がわずかに 散見されるほかは，ち密な酸化層 を形成している。 $\beta_{2}^{\prime}$ もほとん亡゙ 同し傾向であるが， $\beta_{3}{ }^{\prime}$ か力 $\beta_{4}^{\prime}$ に移行するにしたがって, 酸化温 度 $1300^{\circ} \mathrm{C}$ の場合と同様な傾向が 観察された。

\section{4. 総括及び結論}

$\beta^{\prime}$-サイアロン $(z=1 \sim 4)$ の加 圧焼結体と $\beta_{2}{ }^{\prime}$ 常圧焼結体につい て, $1200^{\circ}$ 及び $1300^{\circ} \mathrm{C}$ の酸化温 度で，酸素ふ儿囲気中で, 24,72 , 168,360 及び 720 時閒の酸化を 行った.

酸化による重量増から，酸化は 第 1 , 第 2 段階の拡散機構で進行 すると考察した。

酸化生成物は，クリストバライ ト，ムライト及び若干のシリケー トガラス相からなり， $\beta_{1}{ }^{\prime} か ら \beta_{4}{ }^{\prime}$

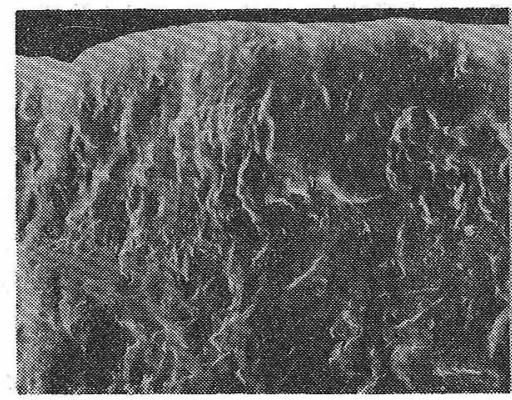

(1) $\beta_{\mathbf{i}}{ }^{\prime}$

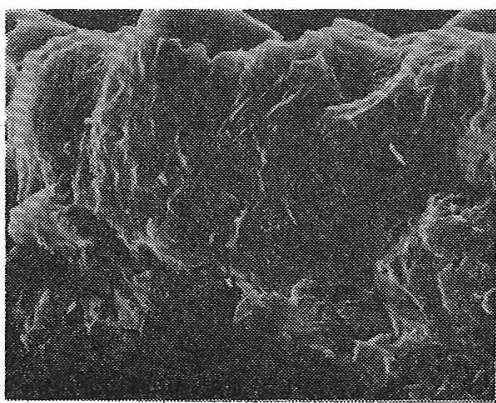

(3) $\beta_{8}^{\prime}$

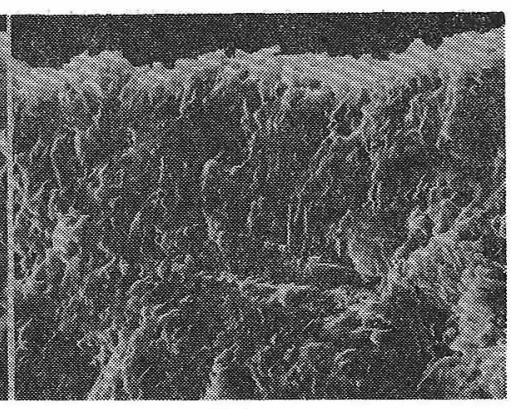

(2) $\beta_{2}^{\prime}$

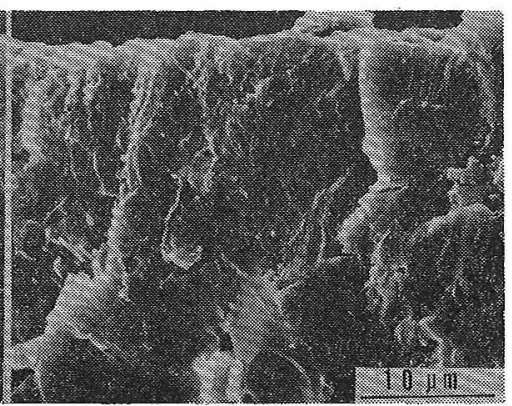

(4) $\beta_{4}{ }^{\prime}$

Fig. 10. Side view of oxidized hot-pressed $\beta^{\prime}$-sialon $(z=1 \sim 4)$.

Oxidation; $1300^{\circ} \mathrm{C}, 30 \mathrm{~d}$.

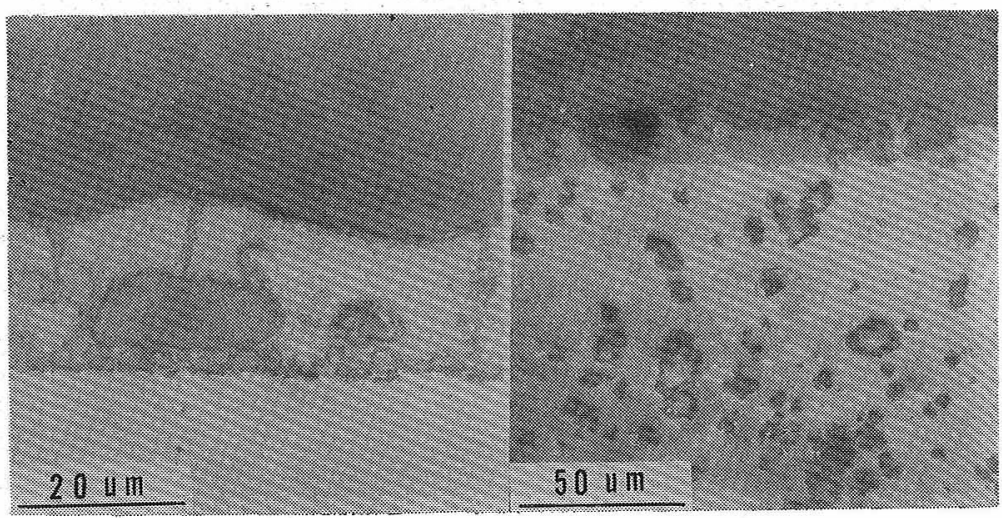

(1) $\beta_{1}^{\prime}$

(2) $\beta_{2}^{\prime}(\mathrm{RS})$

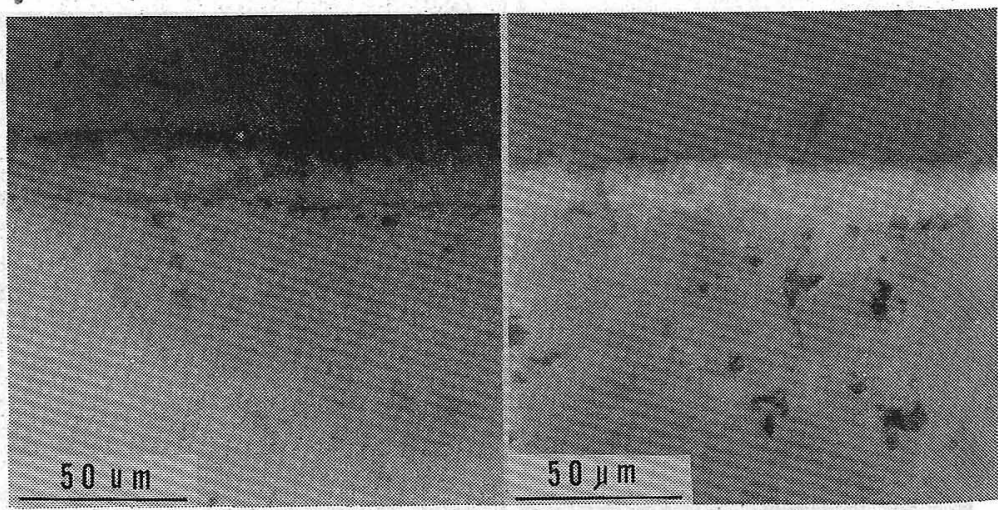

(3) $\beta_{3}{ }^{\prime}$

(4) $\beta_{4}{ }^{\prime}$

Fig. 11. Optical microscopy observation of polished side view of $\beta^{\prime}$-sialon. Oxidation; $1300^{\circ} \mathrm{C}, 30 \mathrm{~d}$. 
に移行するにしたがってクリストバライト相は減少し， ムライト相は増加する， $\beta_{4}{ }^{\prime}$ では，酸化膜の主成分はム ライト相のみで, クリストバライトは認められなかっ た.

酸化物の表面形状の観察結果からも, 酸化は第 1 , 第 2 段階の拡散律速に従うことを示した.

酸化膜の断面性状は $\beta_{1}{ }^{\prime}$ から $\beta_{4}{ }^{\prime}$ に移行するにした がって, 膜厚は増大し, そして気泡群を含むち密な酸化 膜から, 微細結晶群を多量に含む, 比較的ポーラスな酸 化膜に変化した.

以上のことから，酸化による拡散律速の結論を引き出 すことは困難であるが, 実験データ及び現象結果から推 定して, サイアロンの酸化は次のような拡散律速に分類 できる

（1）焼結体粒界層中に存在する不純物（特に液相生 成イオン）の拡散による律速段階の寄与率は,

$$
\beta_{1}{ }^{\prime}>\beta_{2}{ }^{\prime}>\beta_{3}{ }^{\prime}>\beta_{4}{ }^{\prime}
$$

であり,

（2）酸素の拡散（細孔内桩散を含む）による律速段 階の寄与率は,

$$
\beta_{1}{ }^{\prime}<\beta_{2}{ }^{\prime}<\beta_{3}{ }^{\prime}<\beta_{4}{ }^{\prime}
$$

$\mathrm{Si}_{3} \mathrm{~N}_{4}-\mathrm{Y}_{2} \mathrm{O}_{3}-\mathrm{Al}_{2} \mathrm{O}_{3}{ }^{15)}, \mathrm{Si}_{3} \mathrm{~N}_{4}-\mathrm{MgO}^{16)}$ 系の加圧焼結体 の酸化に比し, $\beta^{\prime}$-サイアロンの耐酸化性は, 重量増, 膜 厚から見て，極めて優れている。

謝辞 本研究を行うに当たって, $\beta_{2}{ }^{\prime}(\mathrm{RS})$ の試料は, 当研 究所に研究生として派遣されて来た徳山曹達 (株), 倉元信行氏 から提供された。 また多数の走查電子顕微鏡写真を精力的に撮 っていただいた, 当研究所技術課, 堤 正幸氏にも併せて感謝 の意を表します。

\section{文献}

1) Y. Oyama and O. Kamigaito, Yogyo-Kyokai-Shi, 80,
327-36 (1972).

2) K.H. Jack and W.I. Wilson, Nature Phys. Sci., 238, [80] 28-29 (1972).

3) K.H. Jack, J. Mater. Sci., 11, 1135-58 (1976).

4) R.J. Lumby, B. North and A.J. Taylor, "Chemistry and Creep of SiAlONS" Special Ceramics 6, edited by P. Popper, British Ceramic Research Asson., Stokeon-Trent, England (1975).

5) L.J. Gauckler, H.L. Lucas and G. Petzow, J. Am. Ceram. Soc., 58, 346-47 (1975).

6) G.K. Laydon, "Process Development for Pressureless Sintering of SiAlON Ceramic Components", Final Report Contract NOOO 19-75-0232, Naval Air System Command, Washington D.C. Feb. 1976.

7) I.K. Naik, L.J. Gauckler and T.Y. Tien, J. Am. Ceram. Soc., 61, 332-35 (1978).

8) N. Kamiýa, Y. Oyama and O. Kamigaito, YogyoKyokai-Shi, 83, 553-57 (1975).

9) M. Mitomo, N. Kuramoto, M. Tsutsumi and H. Suzuki, Yogyo-Kyokai-Shi, 86, 526-31 (1978).

10) M. Mitomo, N. Kuramoto and Y. Inomata, J. Mater. Sci., 14, 2309-16 (1979).

11) S.C. Singhal and F.F. Lange, J. Am. Ceram. Soc., 60, 190-91 (1977)

12) J. Schlichting, "Nitrogen Ceramics", edited by F.L. Riley, Nordhoff-Leyden (1977).

13) M.H. Lewis and P. Barnard, J. Mater. Sci., 15, 443 -48 (1980).

14) R.W. Davidge, A.G. Evans, D. Gilling and P.R. Wilyman, Proceeding of the Fifth Symposium on Special Ceramics, 329-42 (1970).

15) Y.T. Hasegawa, H.H. Tanaka, M. Tsutsumi and H. Suzuki, Yogyo-Kyokai-Shi, 88, 292-97 (1980).

16) Y.T. Hasegawa, T. Yamane, K. Hirota and H. Suzuki, Yogyo-Kyokai-Shi, 89, 46-54 (1981).

17) M. Mitomo and N. Kuramoto, Yogyo-Kyokai-Shi, 87, 141-46 (1979).

18) Sin-Shong Lin, J. Am. Ceram. Soc., 58, 160 (1975).

19) E.M. Levin, C.R. Robbins and H.M. McMurdie, "Phase Diagram for Ceramists" edited by M.K. Reser, Am. Ceram. Soc. Inc., Columbus, OH (1964). 